\title{
Botanicals as Grain Protectants
}

\author{
Yallappa Rajashekar, ${ }^{1}$ Nandagopal Bakthavatsalam, ${ }^{1}$ and Thimmappa Shivanandappa $^{2}$ \\ ${ }^{1}$ National Bureau of Agriculturally Important Insects, P. Bag No:2491, H.A. Farm Post, Bellary Road, \\ Karnataka, Bangalore 560 024, India \\ ${ }^{2}$ Department of Zoology, University of Mysore, Manasagangotri, Karnataka, Mysore 560007, India
}

Correspondence should be addressed to Yallappa Rajashekar, rajacftri@yahoo.co.in

Received 12 April 2012; Revised 8 June 2012; Accepted 14 June 2012

Academic Editor: John T. Trumble

Copyright ( 2012 Yallappa Rajashekar et al. This is an open access article distributed under the Creative Commons Attribution License, which permits unrestricted use, distribution, and reproduction in any medium, provided the original work is properly cited.

\begin{abstract}
Prevention of food losses during postharvest storage is of paramount economic importance. Integrated pest management is now a widely accepted strategy in pest control including postharvest infestation control which involves the use of chemical (contact/residual) insecticides along with fumigants. The use of synthetic chemical insecticides is either not permitted or used restrictively because of the residue problem and health risks to consumers. In view of the above, there is a need for plants that may provide potential alternatives to the currently used insect control agents as they constitute a rich source of bioactive molecules. Available literature indicates that plant could be source for new insecticides. Therefore, there is a great potential for a plant-derived insecticidal compounds. This paper focuses on the current state of the botanical insecticides as grain protectants and its mode of action.
\end{abstract}

\section{Introduction}

Food grain losses due to insect infestation during storage are a serious problem, particularly in the developing countries $[1,2]$. Losses caused by insects include not only the direct consumption of kernels, but also accumulation of exuviae, webbing, and cadavers. High levels of the insect detritus may result in grain that is unfit for human consumption and loss of the food commodities, both, in terms of quality and quantity. Insect infestation-induced changes in the storage environment may cause warm moist "hotspots" that provide suitable conditions for storage fungi that cause further losses. It is estimated that more than 20,000 species of field and storage pests destroy approximately one-third of the world's food production, valued annually at more than $\$ 100$ billion among which the highest losses (43\%) occurring in the developing world $[3,4]$. The quantitative and qualitative damage to stored grains and grain product from the insect pests may amount to $20-30 \%$ in the tropical zone and 5$10 \%$ in the temperate zone $[5,6]$. Food grain production in India has reached 250 million tonnes in the year 2010-2011, in which nearly $20-25 \%$ food grains are damaged by stored grain insect pests $[7,8]$. The efficient control and removal of stored grain pests from food commodities has long been the goal of entomologists throughout the world.

The major pests of stored grain and pulses of the Indian subcontinent are classified in to two groups, namely, primary pests: those which are capable of penetrating and infesting intact kernel of grain and have immature stages develop within kernel of grain and secondary pests which cannot infest the whole grain but feed on as broken kernels, debris, high moisture weed seeds, and grain damaged by primary pests. In general, the immature stages of the secondary pest species are found external to the grain. It is often thought that secondary invaders cannot initiate infestation. The important primary pests are the rice weevil, Sitophilus oryzae (L.), granary weevil, Sitophilus granaries (L.), (Coleoptera: Curculionidae), lesser grain borer, Rhyzopertha dominica (F.), (Coleoptera: Bostrichidae), Khapra beetle, Trogoderma granarium (Everts), (Coleoptera: Dermestidae), and the pulse beetle Callosobruchus chinensis (L.) (Coleoptera: Bruchidae). The secondary pests are rust-red flour beetle, Tribolium castaneum (Herbst), (Coleoptera: Tenebrionidae), rusty grain beetle, Cryptolestes ferrugineus (L.), (Coleoptera: Cucujidae), 
sawtoothed grain beetle, Oryzaephilus surinamensis (L.), (Coleoptera: Silvanidae), mites, (Acarina: Tetranychidae) Liposcelis corrodens, and (Psocoptera: Liposcelidae).

\section{Infestation Control by Pesticides and Their Side Effects}

Since the 1950s, synthetic insecticides have been used extensively in grain facilities to control stored product insect pests. Fumigants such as methyl bromide, phosphine, cyanogens, ethyl formate, or sulfuryl fluoride rapidly kill all life stages of stored product insects in a commodity or in a storage structure. Fumigation is still one of the most effective methods for the prevention of stored product losses from insect pests. But pests develop resistance, not stored products were showing a slow upsurge in fumigation resistance [9]. Resistance to phosphine is so high in Australia and India, it may cause control failures $[10,11]$. Methyl bromide has been identified as a major contributor to ozone depletion [12] and has been banned in developed countries, and developing nations have committed to reducing the use by $20 \%$ in 2005 and phase out in 2015. Contact insecticides such as malathion, chlorpyrifos, or deltamethrin are sprayed directly on grain or storage structure for protection from infestation for several months. The incidence of insecticide resistance is a growing problem in stored-product protection. Resistance to one or more insecticides has been reported in at least 500 species of insects and mites [13].

Champ [14] reported that resistance to pesticides used to protect grain and other stored food stuffs is widespread and involves all groups of pesticides and most of the important pests. Some of the contact insecticides have become ineffective because of widespread resistance in insect population. Resistance to malathion is widespread in Canada, USA and Australia [15]. Stored product insects pests were found to be resistant against different insecticides including the cyclodienes, chlorpyrifos, cyanophos, carbamates, carbaryl, cypermethrin, dichlorodiphenyltrichloroethane, deltamethrin, diazinon, dichlorovos, ethylene bromide, ethyl formate organophosphates, permethrin, pyrethrins, and propoxur.

Although chemical insecticides are effective, their repeated use has led to residual toxicity, environmental pollution and an adverse effect on food besides side effect on humans $[16,17]$. Their uninterrupted and indiscriminate use not only has led to the development of resistant strains but also accumulation of toxic residues on food grains used for human consumption that has led to the health hazards [18]. In view of all these problems, several insecticides have either been banned or restricted in their use.

\section{Botanicals as Alternative to Synthetic Pesticides}

The increasing serious problems of resistance and residue to pesticides and contamination of the biosphere associated with large-scale use of broad spectrum synthetic pesticides have led to the need for effective biodegradable pesticides with greater selectivity. This awareness has created a worldwide interest in the development of alternative strategies, including the discovery of newer insecticides $[19,20]$. However, newer insecticides will have to meet entirely different standards. They must be pest specific, nonphytotoxic, nontoxic to mammals, ecofriendly, less prone to pesticide resistance, relatively less expensive, and locally available [21]. This has led to re-examination of the century-old practices of protecting stored products using plant-derivatives, which have been known to resist insect attack [5, 22-24]. Plant derived materials are more readily biodegradable, less likely to contaminate the environment and nay be less toxic to mammals. There are many examples of very toxic plant compounds. Therefore, today, researchers are seeking new classes of naturally occurring insecticides that might be compatible with newer pest control approaches $[2,25,26]$.

Since ancient times, there have been efforts to protect harvest production against pests. The Egyptian and Indian farmers used to mix the stored with fire ashes $[83,84]$. The ancient Romans used false hellebore (Veratrum album) as a rodenticide, the Chinese is credited with discovering the insecticidal properties of Derris species, whereas pyrethrum was used as an insecticide in Persia and China [4]. In many parts of the world, locally available plants are currently in wide use to protect stored products against damage caused by insect infestation [80, 85-87]. Indian farmers used neem leaves and seed for the control of stored grain pests [88]. In northern Cameroon, cowpeas are traditionally mixed with sieved ash after threshing and the mixture put into mud granaries or clay jars [89]. In eastern Africa, leaves of the wild shrub Ocimum suave and the cloves of Eugenia aromatic are traditionally used as stored grain protectants [90]. In Rwanda, farmers store edible beans in a traditional closed structure (imboho) and whole leaves of Ocimum canum are usually added to the stored foodstuff to prevent insect damage within these structures [75]. Owusu [91] suggested natural and cheaper methods for the control of stored product pests of cereals, with traditionally useful Ghanaian plant materials. In some south Asian countries, food grains such as rice or wheat are traditionally stored by mixing with $2 \%$ turmeric powder $[92,93]$. The use of oils in stored-products pest control is also an ancient practice. Botanical insecticides such as pyrethrum, derris, nicotine, oil of citronella, and other plant extracts have been used for centuries [27, 94, 95]. More than 150 species of forest and roadside trees in India produce oilseeds, which have been mainly used for lighting, medicinal purposes, and also as insecticides from ancient times to early 20th century [96]. Turmeric, garlic, Vitex negundo, gliricidia, castor, Aristolochia, ginger, Agave americana, custard apple, Datura, Calotropis, Ipomoea, and coriander are some of the other widely used botanicals to control and repel crop pests $[81,97]$.

Talukder [5] has listed 43 plant species as insect repellents, 21 plants as insect feeding deterrents, 47 plants as insect toxicants, 37 plants as grain protectants, 27 plants as insect reproduction inhibitors, and 7 plants as insect growth and development inhibitors. Eighteen species showed insecticidal 
potential, and antiovipositional properties against Sitophilus oryzae [98].

\section{Classification of Botanical Insecticides}

On the basis of physiological activities on insects, Jacobson [3] conventionally classified the plant components into 6 groups, namely, repellents, feeding deterrents/antifeedants, toxicants, growth retardants, chemosterilants, and attractants. Focus on the toxicants and grain protectants on activity of essential oil, extracts, and its constituents has sharpened since the 1980s.

4.1. Repellents. The repellents are desirable chemicals as they offer protection with minimal impact on the ecosystem, as they drive away the insect pest from the treated materials by stimulating olfactory or other receptors. Repellents from plant origins are considered safe in pest control; minimise pesticide residue; ensure safety of the people, food, and environment $[1,5,99]$. The plant extracts, powders, and essential oil from the different bioactive plants were reported as repellent against stored grain insect pests $[1,91,100-102]$. For example, the essential oil of Artemisia annua was found as repellent against Tribolium castaneum and Callosobruchus maculates [103].

4.2. Antifeedants/Feeding Deterrents. Antifeedants, sometimes referred to as "feeding deterrents" are defined as chemicals that inhibit feeding or disrupt insect feeding by rendering the treated materials unattractive or unpalatable [104, 105]. Some naturally occurring antifeedants, which have been characterized, include glycosides of steroidal alkaloids, aromatic steroids, hydroxylated steroid meliantriol, triterpene hemiacetal, and others [3, 106]. Essential oil constituents such as thymol, citronellal and $\alpha$-terpineol are effective as feeding deterrent against tobacco cutworm, Spodoptera litura synergism, or additive effects of combination of monoterpenoids from essential oils have been reported against Spodoptera litura larvae [107]. The screening of several medicinal herbs showed that root bark of Dictamnus dasycarpus possessed significant feeding deterrence against two stored-product insects [108].

4.3. Toxicants. Research on new toxicants of plant origin has not declined in recent years despite the increased research devoted to the discovery of synthetic insecticides [25]. Worldwide reports on plant derivates showed that many plant products are toxic to stored product insects $[6,16$, $27,55,82,91,109-114]$. Talukder [32] listed the use of 43 plant species expressing toxicant effects of different species of stored-products insects. Pascual-Villalobos and Robledo [115] carried out screening of plant extracts from 50 different wild plant species of southeastern Spain for insecticidal activity towards Tribolium castaneum and reported that four species, namely, Anabasis hispanica, Senecio lopezii, Bellardia trixago, and Asphodelus fistulosus were found be promising. Two major constituents of the essential oil of garlic, Allium sativum, methyl allyl disulfide and diallyl trisulfide were to be potent toxicant and fumigants against Sitophilus zeamais and Tribolium castaneum [116]. Rahman [117] reported that nicotine, an active component of Nicotiana tabacum, is a strong organic poison which acts as a contact-stomach poison with insecticidal properties. This compound is, of course, very toxic to humans as well. The essential oil vapours distilled from anise, cumin, eucalyptus, oregano, and rosemary were also reported as fumigantants and caused $100 \%$ mortality of the eggs of Tribolium confusum and Ephestia kuehniella [118]. Many species of the genus Ocimum oils, extracts, and their bioactive compounds have been reported to have insecticidal activities against various insect species $[59,119]$. A list of many known toxicants from plant origin, reported as effective on stored-product insect-pest management, is given in Table 1.

4.4. Natural Grain Protectants. From very early times, plant materials have been used as natural protectants of stored grains. Worldwide reports indicate that when mixed with stored grains, leaf, bark, seed powder, or oil extracts of plants reduce oviposition rate and suppress adult emergence of stored product insects, and also reduce seed damage rates [25, 40, 46, 87, 119-122]. In 1989, Jacobson [123] noted that the most promising natural grain protectants were generally observed in the plant families, Annonaceae, Asteraceae, Canellaceae, Labiatae, Meliaceae, and Rutaceae.

The Indian neem plant is the most well-known example and its various parts, namely, leaves, crushed seeds, powdered fruits, oil, and so forth, have been used to protect stored grain from infestation $[1,124,125]$. The neem oil and kernel powder gave effective grain protection against stored grain insect pests like Sitophilus oryzae, Tribolium cataneum, Rhyzopertha dominica, and Callosobruchus chinensis at the rate of 1 to $2 \%$ kernel powder or oil [126]. The neem oil adhered to grain forms uniform coating around the grains against storage pests for a period of 180-330 days [127]. Yadava and Bhatnagar [128] reported that a dried leaves of Azadirachta indica have been mixed with stored grains for protection against insects. Azadirachtin is an active principle from the neem plant, which is an effective grain protectant against insect infestation [129]. Rajashekar et al. [7] reported that root powder extracts of Decalepis hamiltonii have been mixed with stored grains for protection against various stored grain insect pests. Eighteen species offered protection to wheat up to 9 months without affecting seed germination [98].

In parts of eastern Africa, leaves of some plants and allelochemicals including azadirachtin, nicotine, and rotenone have traditionally been used as grain protectants $[5,130]$. The powders of Rauvolfia serpentina, Acorus calamus, and Mesua ferrea are used as a grain protectant against Rhyzopertha dominica [131]. In a survey in northern semiarid regions of Ghana only 16 plants were identified as being used as grain protectants [132]. In Africa, the grain protectant potential of different plant derivatives, including plant oils against major stored-product pests were also found to be very promising and reduced the risks associated with the use of insecticides $[82,121]$. In northern Cameroon, the 
TABLE 1: List of plant species reported to show insecticidal activity.

\begin{tabular}{|c|c|c|c|}
\hline Plant species & Family & Plant part & References \\
\hline Acorus calamus & Acoraceae & $\mathrm{O}, \mathrm{RO}$ & [27] \\
\hline Allium sativum & Alliaceae & $\mathrm{P}$ & {$[28]$} \\
\hline Annona squamosa & Annonaceae & $\mathrm{L}$ & {$[29]$} \\
\hline Aphanamixis polystachya & Meliaceae & SC, SE & {$[25]$} \\
\hline Azadirachta indica & Meliaceae & O, SP, LP & {$[30]$} \\
\hline Baccharis salicifolia & Asteraceae & $\mathrm{O}$ & {$[31]$} \\
\hline Bassia longifolia & Sapotaceae & $\mathrm{E}$ & {$[5]$} \\
\hline Brassica spp. & Cruciferae & $\mathrm{L}, \mathrm{ZE}$ & {$[32]$} \\
\hline Cajanus cajan & Fabaceae & $\mathrm{O}$ & {$[33]$} \\
\hline Calophyllum inophyllum & Clusiaceae & $\mathrm{O}$ & {$[34]$} \\
\hline Calotropis procera & Apocynaceae & LP & {$[35]$} \\
\hline Carum carvi & Apiaceae & $\mathrm{FE}$ & {$[36]$} \\
\hline $\begin{array}{l}\text { Cinnamomum } \\
\text { aromaticum }\end{array}$ & Lauraceae & $\mathrm{B}$ & {$[37]$} \\
\hline Citrus & Rutaceae & $\mathrm{O}$ & {$[38]$} \\
\hline Curcuma longa & Zingiberaceae & $\mathrm{P}$ & {$[39]$} \\
\hline $\begin{array}{l}\text { Chenopodium } \\
\text { ambrosioides }\end{array}$ & Amaranthaceae & $\mathrm{FE}, \mathrm{O}$ & {$[40]$} \\
\hline Cocos nucifera & Arecaceae & $\mathrm{O}$ & {$[25]$} \\
\hline Convolvulus arvensis & Convolvulaceae & LE & {$[41]$} \\
\hline Conyza dioscoridis & Asteraceae & $\mathrm{ZE}$ & {$[41]$} \\
\hline Coriandrum sativum & Apiaceae & $\mathrm{SE}, \mathrm{O}$ & {$[42]$} \\
\hline Datura alba & Solanaceae & LP & {$[43]$} \\
\hline Decalepis hamiltonii & Asclepiadaceae & $\mathrm{XP}$ & {$[7]$} \\
\hline Eichhornia crassipes & Pontederiaceae & LE & {$[44]$} \\
\hline Elaeis guineensis & Arecaceae & $\mathrm{O}$ & {$[45]$} \\
\hline Elaeis guineensis & Palmaceae & $\mathrm{O}$ & {$[46]$} \\
\hline Embelia ribes & Myrsinaceae & $\mathrm{FE}, \mathrm{O}$ & {$[47]$} \\
\hline Eucalyptus globules & Myrtaceae & LP, M & {$[48]$} \\
\hline Foeniculum vulgare & Apiaceae & FE & {$[49]$} \\
\hline Glycine max & Fabaceae & $\mathrm{O}$ & {$[50]$} \\
\hline Jatropha gossypifolia & Euphorbiaceae & SE & {$[51]$} \\
\hline Juniperus virginiana & Cupressaceae & $\mathrm{O}$ & {$[52]$} \\
\hline Lantana camara & Verbenaceae & $\mathrm{TE}$ & {$[45]$} \\
\hline Lonchocarpus spp. & Leguminosae & $\mathrm{O}$ & {$[53]$} \\
\hline Lupinus albus & Fabaceae & SE & {$[54]$} \\
\hline Lupinus termis & Leguminosae & $\mathrm{SE}$ & {$[54]$} \\
\hline Melia azedarach & Meliaceae & $\mathrm{O}, \mathrm{E}$ & {$[55]$} \\
\hline Mentha citrate & Lamiaceae & $\mathrm{O}$ & {$[56]$} \\
\hline Nicotiana tabacum & Solanaceae & $\mathrm{E}$ & {$[57]$} \\
\hline Ocimum canum & Lamiaceae & LP & {$[58]$} \\
\hline $\begin{array}{l}\text { Ocimum } \\
\text { kilimandscharicum }\end{array}$ & Lamiaceae & $\mathrm{O}$ & {$[59]$} \\
\hline Piper nigrum & Piperaceae & $\mathrm{O}, \mathrm{E}$ & {$[60,61]$} \\
\hline Polygonum hydropiper & Polygonaceae & $\mathrm{L}$ & {$[62]$} \\
\hline Pongamia glabra & Fabaceae & $\mathrm{O}, \mathrm{E}$ & {$[61]$} \\
\hline Psidium guajava & Myrtaceae & $\mathrm{L}, \mathrm{LP}$ & {$[63]$} \\
\hline
\end{tabular}

TABLE 1: Continued.

\begin{tabular}{lccc}
\hline Plant species & Family & Plant part & References \\
\hline Ryania speciosa & Flacourtiaceae & YE & {$[64]$} \\
Sapindus trifoliatus & Sapindaceae & SP & {$[65]$} \\
Schleichera trijuga & Sapindaceae & O & {$[66]$} \\
Sesamum orientale & Pedaliaceae & O & {$[5]$} \\
Sesamum indicum & Pedaliaceae & O & {$[67]$} \\
Syzygium aromaticum & Myrtaceae & O & {$[68]$} \\
Tagetes erecta & - & $\mathrm{X}, \mathrm{Y}$ & {$[69]$} \\
Tanacetum & Asteraceae & $\mathrm{O}, \mathrm{P}$ & {$[55]$} \\
cinerariaefolium & Cupressaceae & $\mathrm{E}$ & {$[64]$} \\
Thujopsis dolabrata & Fabaceae & SE & {$[70]$} \\
Trigonella & & & {$[71]$} \\
foenumgraecum & Lamiaceae & $\mathrm{L}$ & \\
Vitex negundo & &
\end{tabular}

Note. L: leaves, B: bark, F: fruits, S: seeds, O: oil, P: powder, E: extract, M: vapour, R: Rhizome, T: plant, V: flower, X: root, and Y: stem, (Source: $[5,6]$ ).

essential oils of plants Xylopia aethiopica, Vepris heterophylla, and Luppia rugosa are used for protection of stored grains from attack of stored grain insect pests [114]. The components of citrus peels were used as grain protectant against Callosobruchus maculatus [133]. Coconut oil has been found effective against Callosobruchus chinensis, for a storage period of six months, when applied to Vigna radiata (green gram) at $1 \%$ [134]. Formulations of menthol were used as protection of pulse grain from attack of Callosobruchus Chinensis [135]. Spinosad, a naturally occurring insecticide from the actinomycete, Saccharopolyspora spinosa, has high efficacy, a broad insect pest spectrum, low mammalian toxicity, and minimal environmental profile is unique among existing products currently used for stored-grain protection [136].

4.5. Chemosterilants/Reproduction Inhibitors. Many researchers reported that plant parts, oil, extracts, and powder mixed with grain-reduced insect oviposition, egg hatchability, postembryonic development, and progeny production [137-139]. Lists of 43 plant species have been reported as reproduction inhibitors against stored product insects [32]. Reports have also indicated that plant derivatives including the essential oils caused mortality of insect eggs [82]. Many ground plant parts, extracts, oils, and vapour also suppress many insects [6,7].

4.6. Insect Growth and Development Inhibitors. Plant extracts showed deleterious effect on the growth and development of insects and reduced larval pupal and adult weight significantly, lengthened the larval and pupal periods, and reduced pupal recovery and adult eclosion [140]. Rajasekaran and Kumaraswami [141] reported that grains coated with plant extracts completely inhibited the development of insect 
TABLE 2: List of insecticidal active principles of plants.

\begin{tabular}{|c|c|c|c|c|}
\hline Active principle & Plant species & Insect toxicity & Insect species & References \\
\hline Anonaine & Annona reticulate & Contact & Callosobruchus chinensis & {$[72]$} \\
\hline Azadirachtin & Azadirachta indica & Contact: IGR & Stored grain pests, aphids & {$[30]$} \\
\hline E-Anethole & Foeniculum vulgare & Contact & $\begin{array}{l}\text { Sitophilus oryzae, } \\
\text { Callosobruchus chinensis }\end{array}$ & {$[49]$} \\
\hline$\beta$-Asarone & Acorus calamus & Contact; & Stored grain pests & {$[73]$} \\
\hline Z-Asarone & $\begin{array}{l}\text { Acorus calamus; } \\
\text { Acorus gramineus }\end{array}$ & Contact & Sitophilus zeamais & {$[26]$} \\
\hline Bornyl acetate & Chamaecyparis obtuse & Contact & Sitophilus oryzae & {$[27]$} \\
\hline Camphor & Ocimum kilimandscharicum & Contact & Sitophilus oryzae & {$[59]$} \\
\hline (+)-3-Carene & Baccharis salicifolia & Contact & Tribolium castaneum & [59] \\
\hline Carvacrol & Thujopsis dolabrata & Contact; fumigant & $\begin{array}{l}\text { Sitophilus oryzae, } \\
\text { Callosobruchus chinensis }\end{array}$ & {$[60]$} \\
\hline Carvone & Carum carvi & Contact & $\begin{array}{l}\text { Sitophilus oryzae, } \\
\text { Rhyzopertha dominica }\end{array}$ & {$[74]$} \\
\hline 1,8 Cineole & Eucalyptus & Contact; fumigant & $\begin{array}{l}\text { Rhyzopertha dominica } \\
\text { Tribolium castaneum }\end{array}$ & {$[38]$} \\
\hline Cinnamaldehyde & Cinnamomum aromaticum & Contact & $\begin{array}{l}\text { Tribolium castaneum, } \\
\text { Sitophilus zeamais }\end{array}$ & {$[37]$} \\
\hline Dioctyl hexanedioate & Conyza dioscoridis & Contact & $\begin{array}{l}\text { Tribolium castaneum, } \\
\text { Sitophilus granaries }\end{array}$ & {$[41]$} \\
\hline Eugenol & Citrus & Fumigant & Sitophilus oryzae & {$[38]$} \\
\hline Estragole & Foeniculum vulgare & Contact & $\begin{array}{c}\text { Sitophilus oryzae } \\
\text { Lasioderma serricorne }\end{array}$ & {$[31]$} \\
\hline$(+)$-Fenchone & Foeniculum vulgare & Contact & $\begin{array}{l}\text { Sitophilus oryzae } \\
\text { Lasioderma serricorne }\end{array}$ & {$[31]$} \\
\hline Hexa decane & Chenopodiumambrosioides & Contact & $\begin{array}{l}\text { Tribolium castaneum, } \\
\text { Sitophilus granaries }\end{array}$ & {$[41]$} \\
\hline Hexadecanoic acid & Convolvulus arvensis & Contact & $\begin{array}{c}\text { Sitophilus oryzae, } \\
\text { Rhyzopertha dominica. }\end{array}$ & {$[41]$} \\
\hline Linalool & Ocimum canum Sims & Fumigant & $\begin{array}{l}\text { Tribolium castaneum, } \\
\text { Sitophilus granaries }\end{array}$ & {$[75]$} \\
\hline Limonene & Citrus & Contact & Tribolium castaneum & {$[27]$} \\
\hline (-)-Limonene & Baccharis salicifolia & Contact; fumigant & Tribolium castaneum & {$[31]$} \\
\hline Nicotine & Nicotiana tabacum & Contact & Mites, aphids, thrips, leafhopper & {$[39]$} \\
\hline Pyrethrin I and II & Tanacetum cinerariaefolium & Contact; stomach poison & Stored grain pests, crop pests & {$[76]$} \\
\hline$\beta$-Pinene & Baccharis salicifolia & Contact & Tribolium castaneum, & {$[27]$} \\
\hline$\alpha$-Pinene & Baccharis salicifolia & Fumigant & Tribolium castaneum, & {$[27]$} \\
\hline Rotenone & Lonchocarpus sp. & Contact; stomach poison & $\begin{array}{l}\text { Crop pests, lace bugs, } \\
\text { Sitophilus oryzae }\end{array}$ & {$[55]$} \\
\hline Ryania & Ryania speciosa & Contact; stomach poison & $\begin{array}{l}\text { Potato beetle, aphids, lace bugs, } \\
\text { stored grain pests }\end{array}$ & {$[77]$} \\
\hline Sabadilla & Schoenocaulon officinale & Contact; stomach poison & $\begin{array}{c}\text { Stinks, thrips, squash bugs, leaf } \\
\text { hoppers, caterpillars }\end{array}$ & {$[78]$} \\
\hline Spinosyn A and D & Saccharopolyspora spinosa & Stomach poison & Stored grain pests & {$[79]$} \\
\hline
\end{tabular}

like Sitophilus oryzae. Plant derivatives also reduce the survival rates of larvae and pupae and adult emergence [101]. Development of eggs and immature stages inside grain kernel were also inhibited by plant derivatives [102]. The crude extract also retarded development and caused mortality of larvae, cuticle melanisation, and high mortality in adults [142].

\section{Some Important Phytochemicals with Insecticidal Properties}

The botanical insecticides that have primarily been used and are commercially available include ryania, rotenone, pyrethrin, nicotine, azadirachtin, and sabadilla (Tables 2 and 3 ). 
TABLE 3: Insecticidal activity and mammalian toxicity of some natural insecticides.

\begin{tabular}{lcc}
\hline Natural insecticides & Insect toxicity* & $\begin{array}{c}\text { Mammalian toxicity } \\
\text { Oral (rat) LD } 50 \\
\text { (mg/kg b.w.) }\end{array}$ \\
\hline Anethole & C, S & 2090 \\
$\beta$-asarone & C, S & 275 \\
Azadirachtin & IGR, R & 13000 \\
Carvacrol & C & 810 \\
1,8-Cineole & C, F & 2480 \\
Cinnamaldehyde & C & 1160 \\
Cuminic aldehyde & C, S & 1390 \\
Eugenol & C, F & 500 \\
Nicotine & C & 50 \\
Pyrethrin I and II & C, S & 1200 \\
Rotenone & S & 350 \\
Ryania & C, S & 750 \\
Sabadilla & C, S & 5000 \\
Spinosad & C & 3738 \\
\hline
\end{tabular}

${ }^{*} \mathrm{C}$ : contact, S: stomach poison, F: fumigant, IGR: insect growth regulator, and R: repellent [80-82].

5.1. Ryania. The active components of ryania are derived from the roots and woody stems of the plant Ryania speciosa, native to Trinidad [143]. Ryania has low mammalian toxicity, with a median lethal dose $\left(\mathrm{LD}_{50}\right)$ of $750 \mathrm{mg} / \mathrm{kg}$ and works as both contact and stomach poison. It has long residual activity among the botanical insecticides. This botanical insecticide has a unique mode of action and affects muscles by binding to the calcium channels in the sarcoplasmic reticulum. This causes calcium ion flow into the cells, and death follows very rapidly [20]. Ryania works best on caterpillars (i.e., codling moth, corn earworm); however, is it also active on a wide range of insects and mites, including potato beetle, lace bugs, aphids and squash bug [144].

5.2. Rotenone. Rotenone is derived from the roots of the two plants: Lonchocarpus sp. and Derris sp. are both legumes originally from the East Indies, Malaya and South America. Rotenone is a moderately of the toxic botanical insecticides, with an $\mathrm{LD}_{50}$ of $132 \mathrm{mg} / \mathrm{kg}$ to mammals [81]. In fact, rotenone is more toxic to mammals than both carbaryl and malathion, two commonly used synthetically derived insecticides. Also, rotenone is extremely toxic to fish [55]. This botanical insecticide works as both contact and stomach poison. Rotenone is slower acting than most other botanical insecticides, taking several days to kill pests; however, pests stop feeding almost immediately. It degrades rapidly in air and sunlight. Rotenone blocks respiration by electron transport on the complex I. Rotenone shows broad spectrum of activity on many insects and mite pests, including leaffeeding beetles, caterpillars, lice, mosquitoes, ticks, fleas, and fire ants [145].
5.3. Pyrethrin/Pyrethrum. Pyrethrin I and II are derived from the seeds or flower of Chrysanthemum cinerariaefolium $[55,146]$ which is grown in Africa, Ecuador, and Kenya. Pyrethrin has a low mammalian toxicity. However, cats are highly susceptible to pyrethrin poisoning. The $\mathrm{LD}_{50}$ of pyrethrin is 1200 to $1,500 \mathrm{mg} / \mathrm{kg}[81,147,148]$. Pyrethrin is one of the oldest household insecticides still available and is fast acting, providing almost immediate "knockdown" of insects following an application. It works as both a contact and a stomach poison. The material has a very short residual activity-degrading rapidly under sunlight, air and moisture, which means that frequent applications may be required. Pyrethrin can be used up until harvest, as there is no waiting interval required between initial application and harvest of food crops [149].

The way pyrethrin kills insects (mode of activity) is by disrupting the sodium and potassium ion-exchange process in insect nerves and interrupting the normal transmission of nerve impulses. Pyrethrin has activity on wide range of insects and mites, including flies, fleas, beetles, and spider mites [150].

5.4. Nicotine. Nicotine, which is derived from Nicotiana tabacum, is toxic to mammals among the botanical insecticides with an $\mathrm{LD}_{50}$ between 50 and $60 \mathrm{mg} / \mathrm{kg}[55,151]$. It is extremely harmful to humans. Nicotine, a fast-acting nerve toxin, works as a contact poison. It kills insects (and humans) through bonding to receptors at the nerve synapses (junctures), causing uncontrolled nerve firing, and by mimicking acetylcholine (Ach) at the nerve-muscle junctions in the central nervous system [152].

Certain plant types, such as roses, may be harmed or injured by nicotine sprays. Nicotine is most effective on soft-bodied insects and mites, including aphids, thrips, leafhoppers, and spider mites. Many caterpillars are resistant to nicotine [153].

5.5. Azadirachtin. Azadirachtin is derived from the tree Azadirachta indica, grown in India and Africa [55]. Azadirachtin has an extremely low mammalian toxicity and is least toxic of the commercial botanical insecticides, with an $\mathrm{LD}_{50}$ of $13,000 \mathrm{mg} / \mathrm{kg}$. Azadirachtin is considered a contact poison; however, it has "some" systemic activity in plants when applied to the foliage. The material is generally nontoxic to beneficial insects and mites. Azadirachtin has broad mode of activity, working as a feeding deterrent, insect-growth regulator, repellent, and sterilant; and it may also inhibit oviposition $[55,154]$. The material is active on a broad range of insects, including stored grain pests, aphids, caterpillars and mealybugs [30].

5.6. Sabadilla. Sabadilla is derived from the seeds of plant Schoenocaulon officinale, which is grown in Venezuela. Sabadilla is one of the least toxic registered botanical insecticides, with mammalian $\mathrm{LD}_{50}$ of $5,000 \mathrm{mg} / \mathrm{kg}$. Sabadilla works as contact toxicant and a stomach poison. Similar to other botanical insecticides, the material has minimal residual activity and degrades rapidly in sunlight and moisture 
(rainfall). Sabadilla works by affecting nerve cell membranes, causing loss of nerve function, paralysis, and death [146]. It is effective against caterpillars, leaf hoppers, thrips, stink, and squash bugs.

5.7. Avermectins. Avermectins, which are macrocyclic lactones, are derived from the actinomycete, Streptomyces avermitilis [155], lethal dosage of $50 \%$ in range of 10 $11.3 \mathrm{mg} / \mathrm{kg}$ for rat. This molecule is most effective against agricultural pests with lethal concentration of $90 \%$ ( $\mathrm{LC}_{90}$ ) in the range of $0.02 \mathrm{ppm}$ for mites and has somewhat least toxicity to stored products pests. It is effective on internal parasites of domestic animals [156]. Avermectins block the neurotransmitter GABA at the neuromuscular junction in insects and mites. Visible activity, such as feeding and egg laying, stops shortly after exposure, though death may not occur for several days [157].

5.8. Spinosads. Spinosad is a mixture of spinosyn A and spinosyn $\mathrm{D}$ and was originally isolated from the soil Actinomycete, Saccharopolyspora spinosa [158]. Spinosad is recommended for the control of a very wide range of caterpillars, leaf miners and foliage-feeding beetles. Spinosyns have a novel mode of action, primarily targeting binding sites on nicotinic acetylcholine receptors that are distinct from those at which other insecticides exert activity, leading to disruption of acetylcholine neurotransmission [79, 159].

5.9. ( $Z$ ) Asarone. ( $Z$ ) Asarone is natural insecticide isolated from Acorus calamus L. [26]. This molecule is more effective against adults of Sitophilus oryzae, Lasioderma serricorne, and Callosobruchus chinensis and shows both fumigant and contact toxicity. Some studies show that the molecules possess in vivo carcinogenic effects [160] and in vitro mutagenic activites [161]. Further, this molecule induces structural chromosome aberration in human lymphocytes in vitro [162]. Due to its mammalian toxicity $[81,163]$, the molecule is unsafe for grain treatment.

\section{Challenges to the Utilization of Botanicals Pesticides}

Many plant species contain secondary metabolites that are potent against several pest species. Not only are some of the plants (e.g., the neem trees) of major interest as sources of phytochemicals for more environmentally benign grain/crop protection. Phytochemical products can increase income of rural farmers and promote safety and quality of food and life in general $[8,164]$.

The successful utilization of botanicals can help to control many of the world's destructive pests and diseases, as well as reduce erosion, desertification, deforestation, and perhaps even reducing human population by acting as spermaticide (although this will be considered a major negative effect by many cultures and religions) [165]. Although the possibilities of using botanical pesticides seem almost endless, many details remain to be clarified. Many obstacles must be overcome and many uncertainties clarified before their potential can be fully realized. These limitations seem surmountable; however, they present exciting challenges to the scientific and economic development communities. Solving the following obstacles and uncertainties may well bring a major new resource which will benefit much of the world. These obstacles include:

(i) lack of experience and appreciation of the efficacy of botanicals for pest control. There are still doubts as to the effectiveness of plant-derived products (both "home-made" and commercial products) due to their slow action and lack of rapid knockdown effect;

(ii) genetic variability of plant species in different localities;

(iii) difficulty of registration and patenting of natural products and lack of standardization of botanical pesticide products;

(iv) economic uncertainties occasioned by seasonal supply of seeds, perennial nature of most botanical trees, and change in potency with location and time with respect to geographical limitations;

(v) handling difficulties as there is no method for mechanizing the process of collecting, storing, or handling the seeds or leaves or flowers from some of the perennial trees;

(vi) instability of the active ingredients when exposed to direct sunlight;

(vii) competition with synthetic pesticides through aggressive advertising by commercial pesticides dealers and commercial-formulated botanicals are more expensive than synthetic insecticides and are not as widely available;

(viii) rapid degradation, although desirable in some respects, creates the need for more precise timing or more frequent applications;

(ix) Data on the effectiveness and long-term (chronic) mammalian toxicity are unavailable for some botanicals, and tolerances for some have not been established.

\section{Conclusion}

Many authors have evaluated the insecticidal (grain protectant) properties of plant products on various species of stored product insect pests. The results clearly show that it is possible to develop methods for grain protectants with reduced use of synthetic chemical insecticides. The main advantages of botanical pesticides are ecofriendly, easily biodegradable, nontoxic to nontarget organisms, and many plant-derived natural products acting against insects could be produced from locally available raw materials. They have been numerous botanical pesticides studied at the laboratory level. Research efforts should focus not only on their efficacy, but also on mammalian toxicity, mode of action in insects, seed germination, effect on nutritional quality, seedling growth, and stability of the compound. The insecticides of 
plant origin could be exploited for the development of novel molecules with highly precise targets for sustainable insect pest management in stored grain.

\section{Acknowledgments}

The authors thank the Director, NBAII, Bangalore, for encouragement and support. The first author acknowledges the Department of Biotechnology, New Delhi, for awarding the postdoctoral research associateship.

\section{References}

[1] F. A. Talukder, M. S. Islam, M. S. Hossain, M. A. Rahman, and M. N. Alam, "Toxicity effects of botanicals and synthetic insecticides on Tribolium castaneum (Herbst) and Rhyzopertha dominica (F.)," Bangladesh Journal of Environment Science, vol. 10, no. 2, pp. 365-371, 2004.

[2] N. K. Dubey, B. Srivastava, and A. Kumar, "Current status of plant products as botanical pesticides in storage pest management," Journal of Biopesticide, vol. 1, no. 2, pp. 182186, 2008.

[3] M. Jacobson, "Plants, insects, and man-their interrelationships," Economic Botany, vol. 36, no. 3, pp. 346-354, 1982.

[4] S. Ahmed and M. Grainge, "Potential of the neem tree (Azadirachta indica) for pest control and rural development," Economic Botany, vol. 40, no. 2, pp. 201-209, 1986.

[5] F. A. Talukder, "Plant products as potential stored product insect management agents-a mini review," Emirates Journal of Agricultural Science, vol. 18, pp. 17-32, 2006.

[6] S. Rajendran and V. Sriranjini, "Plant products as fumigants for stored-product insect control," Journal of Stored Products Research, vol. 44, no. 2, pp. 126-135, 2008.

[7] Y. Rajashekar, N. Gunasekaran, and T. Shivanandappa, "Insecticidal activity of the root extract of Decalepis hamiltonii against stored-product insect pests and its application in grain protection," Journal of Food Science and Technology, vol. 47, no. 3, pp. 310-314, 2010.

[8] Y. Rajashekar and T. Shivanandappa, "A novel natural insecticide molecule for grain protection," in Stored Products Protection, M. O. Carvalho, P. G. Fields, C. S. Adler et al., Eds., Proceedings of the 10th International Working Conference on Stored Product Protection, pp. 913-917, Julius-KühnArchiv 425, 2010.

[9] E. J. Donahaye, "Current status of non-residual control methods against stored product pests," Crop Protection, vol. 19, no. 8-10, pp. 571-576, 2000.

[10] B. C. Leelaja, Y. Rajashekar, P. Vanitha Reddy, K. Begum, and S. Rajendran, "Enhanced fumigant toxicity of allyl acetate to stored-product beetles in the presence of carbon dioxide," Journal of Stored Products Research, vol. 43, no. 1, pp. 45-48, 2007.

[11] Y. Rajashekar, P. V. Reddy, K. Begum, B. C. Leelaja, and S. Rajendran, "Studies on aluminium phosphide tablet formulation," Pestology, vol. 30, no. 4, pp. 41-45, 2006.

[12] WMO, "Scientific assessment of ozone depletion: 1994," Global Ozone Research and Monitoring Project 37, Genoa, Italy, 1995.

[13] G. P. Georghiou, "Over view of insecticide resistance," in Managing Resistance to Agrochemicals: From Fundamental Research to Practical Strategies, M. B. Green, H. M. Lebaron, and W. K. Moberg, Eds., vol. 421 of ACS Symposium Series, pp. 19-41, American Chemical Society, Washington, DC, USA, 1990

[14] B. R. Champ, "Occurrence of resistance to pesticides in grain storage pests," in Pesticides and Humid Tropical Grain Storage System, B. R. Champ and E. Highly, Eds., vol. 14 of Proceedings of an International Seminar, Manila 1985. Canberra ACIAR proceedings, pp. 225-229, 1985.

[15] B. Subramanyam and D. W. Hagstrum, "Resistance measurement and management," in Integrated Management of Insects in Stored Products, B. Subramanyam and D. W. Hagstrum, Eds., pp. 331-397, Marcel Dekker, New York, NY, USA, 1995.

[16] S. C. Dubey, M. Suresh, and B. Singh, "Evaluation of Trichoderma species against Fusarium oxysporum f. sp. ciceris for integrated management of chickpea wilt," Biological Control, vol. 40, no. 1, pp. 118-127, 2007.

[17] R. Kumar, A. K. Mishra, N. K. Dubey, and Y. B. Tripathi, "Evaluation of Chenopodium ambrosioides oil as a potential source of antifungal, antiaflatoxigenic and antioxidant activity," International Journal of Food Microbiology, vol. 115, no. 2, pp. 159-164, 2007.

[18] K. Sharma and N. M. Meshram, "Bioactivity of essential oils from Acorus calamus and Syzygium aromaticum, against Sitophilus oryzae (L.) in stored wheat," Biopesticide International, vol. 2, pp. 144-152, 2006.

[19] J. V. D. Heyde, R. C. Saxena, and H. Schmutterer, "Neem oil and neen extracts as potential insecticide for control of Hemipterous rice pests," in Proceedings of the 2nd International Neem Conference, pp. 337-390, Rauischholzhausen, Germany, 1984.

[20] F. E. Dayan, C. L. Cantrell, and S. O. Duke, "Natural products in crop protection," Bioorganic and Medicinal Chemistry, vol. 17, no. 12, pp. 4022-4034, 2009.

[21] W. Hermawan, S. Nakajima, R. Tsukuda, K. Fujisaki, and F. Nakasuji, "Isolation of an antifeedant compound from Andrographis paniculata (Acanthaceae) against the diamond back, Plutella xylostella (Lepidoptera: Yponomeutidae)," Applied Entomology and Zoology, vol. 32, no. 4, pp. 551-559, 1997.

[22] N. E. S. Lale, "A laboratory study of the comparative toxicity of products from three spices to the maize weevil," Postharvest Biology and Technology, vol. 2, no. 1, pp. 61-64, 1992.

[23] F. K. Ewete, J. T. Arnason, J. Larson, and B. J. R. Philogene, "Biological activities of extracts from traditionally used Nigerian plants against the European corn borer, Ostrinia nubilalis," Entomologia Experimentalis et Applicata, vol. 80, no. 3, pp. 531-537, 1996.

[24] K. Sahayaraj, "Common plants oils in agriculture and storage pests management," Green Farming, vol. 1, no. 2, pp. 48-49, 2008.

[25] F. A. Talukder and P. E. Howse, "Laboratory evaluation of toxic and repellent properiies of the pitharaj tree, Aphanamixis polstachya Wall \& Parker, against Sitophilus oryzae (L.)," International Journal of Pest Management, vol. 40, pp. 274-279, 1995.

[26] Y. Yingjuan, C. Wanlun, Y. Changju, X. Dong, and H. Yanzhang, "Isolation and characterization of insecticidal activity of (Z)-asarone from Acorus calamus (L.)," Insect Science, vol. 15, no. 3, pp. 229-236, 2008.

[27] C. Park, S. I. Kim, and Y. J. Ahn, "Insecticidal activity of asarones identified in Acorus gramineus rhizome against three coleopteran stored-product insects," Journal of Stored Products Research, vol. 39, no. 3, pp. 333-342, 2003.

[28] I. L. K. Park and S. C. Shin, "Fumigant activity of plant essential oils and components from garlic (Allium sativum) 
and clove bud (Eugenia caryophyllata) oils against the Japanese termite (Reticulitermes speratus Kolbe)," Journal of Agricultural and Food Chemistry, vol. 53, no. 11, pp. 43884392, 2005.

[29] J. A. Leatemia and M. B. Isman, "Toxicity and antifeedant activity of crude seed extracts of Annona squamosa (Annonaceae) against lepidopteran pests and natural enemies," International Journal of Tropical Insect Science, vol. 24, no. 2, pp. 150-158, 2004.

[30] E. D. Morgan, "Azadirachtin, a scientific gold mine," Bioorganic and Medicinal Chemistry, vol. 17, no. 12, pp. 40964105, 2009.

[31] M. García, O. J. Donadel, C. E. Ardanaz, C. E. Tonn, and M. E. Sosa, "Toxic and repellent effects of Baccharis salicifolia essential oil on Tribolium castaneum," Pest Management Science, vol. 61, no. 6, pp. 612-618, 2005.

[32] F. A. Talukder, Isolation and characterization of the active secondary pithraj (Aphanamixis polystachya) compounds in controlling stored-product insect pests [Ph.D. thesis], University of Southampton, Southampton, UK, 1995.

[33] E. R. Prasad, H. Merzendorfer, C. Madhurarekha, A. Dutta-Gupta, and K. Padmasree, "Bowman-birk proteinase inhibitor from Cajanus cajan seeds: purification, characterization, and insecticidal properties," Journal of Agricultural and Food Chemistry, vol. 58, no. 5, pp. 2838-2847, 2010.

[34] A. F. Traboulsi, K. Taoubi, S. El-Haj, J. M. Bessiere, and S. Rammal, "Insecticidal properties of essential plant oils against the mosquito Culex pipiens molestus (Diptera: Culicidae)," Pest Management Science, vol. 58, no. 5, pp. 491-495, 2002.

[35] M. Singh, K. Lal, and S. B. Singh, "Effect of calotropis (Calotropis procera) extract on infestation of termite (Odontotermes obesus) in sugarcane hybrid," Indian Journal of Agricultural Sciences, vol. 72, no. 7, pp. 439-441, 2002.

[36] M. C. Digilio, E. Mancini, E. Voto, and V. De Feo, "Insecticide activity of Mediterranean essential oils," Journal of Plant Interactions, vol. 3, no. 1, pp. 17-23, 2008.

[37] I. K. Park, H. S. Lee, S. G. Lee, J. D. Park, and Y. J. Ahn, "Insecticidal and fumigant activities of Cinnamomum cassia bark-derived materials against Mechoris ursulus (Coleoptera: Attelabidae)," Journal of Agricultural and Food Chemistry, vol. 48, no. 6, pp. 2528-2531, 2000.

[38] H. T. Prates, J. P. Santos, J. M. Waquil, J. D. Fabris, A. B. Oliveira, and J. E. Foster, "Insecticidal activity of monoterpenes against Rhyzopertha dominica (F.) and Tribolium castaneum (Herbst)," Journal of Stored Products Research, vol. 34, no. 4, pp. 243-249, 1998.

[39] A. K. Tripathi, V. Prajapati, N. Verma et al., "Bioactivities of the leaf essential oil of Curcuma longa (var. ch-66) on three species of stored-product beetles (Coleoptera)," Journal of Economic Entomology, vol. 95, no. 1, pp. 183-189, 2002.

[40] L. A. Tapondjou, C. Adler, H. Bouda, and D. A. Fontem, "Efficacy of powder and essential oil from Chenopodium ambrosioides leaves as post-harvest grain protectants against sixstored product beetles," Journal of Stored Products Research, vol. 38, no. 4, pp. 395-402, 2002.

[41] G. S. Peterson, M. A Kandil, M. D. Abdallah, and A. A. A. Fraq, "Isolation and characterization of biologically-active compounds from some plant extracts," Pesticide Science, vol. 25, pp. 337-342, 1989.

[42] M. S. Islam, M. M. Hasan, W. Xiong, S. C. Zhang, and C. L. Lei, "Fumigant and repellent activities of essential oil from Coriandrum sativum (L.) (Apiaceae) against red flour beetle
Tribolium castaneum (Herbst) (Coleoptera: Tenebrionidae)," Journal of Pest Science, vol. 82, no. 2, pp. 171-179, 2009.

[43] S. Ahamed, F. Shakil, M. A. Riaz, and A. Hussain, "Comparative efficacy of Datura alba nees, Calotropis procera and Imidacloprid on termites in sugarcane at Faisalabad," Pakistan Entomology, vol. 27, no. 2, pp. 11-14, 2005.

[44] R. Charudattan, "Integrated control of water hyacinth Eichhornia crassipes with a pathogen, insects, and herbicides," Weed Science, vol. 34, pp. 26-30, 1986.

[45] H. Bouda, L. A. Tapondjou, D. A. Fontem, and M. Y. D. Gumedzoe, "Effect of essential oils from leaves of Ageratum conyzoides, Lantana camara and Chromolaena odorata on the mortality of Sitophilus zeamais (Coleoptera, Curculionidae)," Journal of Stored Products Research, vol. 37, no. 2, pp. 103109, 2001.

[46] D. Obeng-Ofori, "Plant oils as grain protectants against infestations of Cryptolestes pusillus and Rhyzopertha dominica in stored grain," Entomologia Experimentalis et Applicata, vol. 77, no. 2, pp. 133-139, 1995.

[47] S. Ahmed and M. Grainge, "Potential of the neem tree (Azadirachta indica) for pest control and rural development," Economic Botany, vol. 40, no. 2, pp. 201-209, 1986.

[48] D. R. Batish, H. P. Singh, R. K. Kohli, and S. Kaur, "Eucalyptus essential oil as a natural pesticide," Forest Ecology and Management, vol. 256, no. 12, pp. 2166-2174, 2008.

[49] D. H. Kim and Y. J. Ahn, "Contact and fumigant activities of constituents of Foeniculum vulgare fruit against three coleopteran stored-product insects," Pest Management Science, vol. 57, no. 3, pp. 301-306, 2001.

[50] J. H. Pankey, J. L. Griffin, B. R. Leonard, D. K. Miller, R. G. Downer, and R. W. Costello, "Glyphosate-insecticide combination effects on weed and insect control in cotton," Weed Technology, vol. 18, no. 3, pp. 698-703, 2004.

[51] S. Phowichit, S. Buatippawan, and V. Bullangpoti, "Insecticidal activity of Jatropha gossypifolia L. (Euphorbiaceae) and Cleome viscosa L. (Capparidacae) on Spodoptera litura (Lepidoptera: Noctuidae). Toxicity and carboxylesterase and glutathione-S-transferase activities studies," Communications in Agricultural and Applied Biological Sciences, vol. 73, no. 3, pp. 611-619, 2008.

[52] J. R. Sabine, "Exposure to an environment containing the aromatic red cedar, Juniperus virginiana: procarcinogenic, enzyme inducing and insecticidal effects," Toxicology, vol. 5, no. 2, pp. 221-235, 1975.

[53] M. Isman, "Pesticides based on plant essential oils," Pesticide Outlook, vol. 10, no. 2, pp. 68-72, 1999.

[54] K. Bermúdez-Torres, J. Martínez Herrera, R. Figueroa Brito, M. Wink, and L. Legal, "Activity of quinolizidine alkaloids from three Mexican Lupinus against the lepidopteran crop pest Spodoptera frugiperda," BioControl, vol. 54, no. 3, pp. 459-466, 2009.

[55] M. B. Isman, "Botanical insecticides, deterrents, and repellents in modern agriculture and an increasingly regulated world," Annual Review of Entomology, vol. 51, pp. 45-66, 2006.

[56] R. Pavela, "Insecticidal activity of some essential oils against larvae of Spodoptera littoralis," Fitoterapia, vol. 76, no. 7-8, pp. 691-696, 2005.

[57] A. Tiwari, M. Lakshamana Kumar, and R. C. Saxena, "Effect of Nicotiana tabacum on Tribolium castaneum," International Journal of Pharmacognosy, vol. 33, no. 4, pp. 348-350, 1995.

[58] A. Delobel and P. Malonga, "Insecticidal properties of six plant materials against Caryedon serratus (Ol.) (Coleoptera: 
Bruchidae)," Journal of Stored Products Research, vol. 23, no. 3, pp. 173-176, 1987.

[59] D. Obeng-Ofori, C. H. Reichmuth, A. J. Bekele, and A. Hassanali, "Toxicity and protectant potential of camphor, a major component of essential oil of Ocimum kilimandscharicum, against four stored product beetles," International Journal of Pest Management, vol. 44, no. 4, pp. 203-209, 1998.

[60] H. C. F. Su and R. Horvat, "Isolation, identification, and insecticidal properties of Piper nigrum amides," Journal of Agricultural and Food Chemistry, vol. 29, no. 1, pp. 115-118, 1981.

[61] S. Sighamony, I. Anees, T. Chandrakala, and Z. Osmani, "Efficacy of certain indigenous plant products as grain protectants against Sitophilus oryzae (L.) and Rhyzopertha dominica (F.)," Journal of Stored Products Research, vol. 22, no. 1, pp. 21-23, 1986.

[62] I. Rahman, I. Gogoi, and S. P. Biswas, "Insecticidal activity of leaf extracts of Polygonum hydropiper Linn. against Odontotermes assamensis Holm. (Isoptera: Termitidae)," Journal of Entomological Research, vol. 6, no. 4, pp. 379-383, 2007.

[63] A. Sharaby, "Evaluation of some Myrtaceae plant leaves as protectants against the infestation by Sitophilus oryzae L. and Sitophilus granaries (L.)," Insect Science and its Application, vol. 9, no. 4, pp. 465-468, 1988.

[64] L. J. Charles, "Toxicity of the botanical insecticide Ryania speciosa to Culex pipiens fatigans Wied," Bulletin of Entomological Reseearch, vol. 45, pp. 403-410, 1954.

[65] S. S. Rahman, M. M. Rahman, S. A. Begum, M. M. R. Khan, and M. M. H. Bhuiyan, "Investigation of Sapindus mukorossi extracts for repellency, insecticidal activity and plant growth regulatory effect," Journal of Applied Science Research, vol. 3, no. 2, pp. 95-101, 2007.

[66] K. L. Mikolajczak, R. V. Madrigal, C. R. Smith, and D. K. Reed, "Insecticidal effects of cyanolipids on three species of stored product insects, European corn borer (Lepidoptera: Pyralidae) larvae, and striped cucumber beetle (Coleoptera: Chrysomelidae)," Journal of Economic Entomology, vol. 77, no. 5, pp. 1144-1148, 1984.

[67] H. F. Khater and D. F. Khater, "The insecticidal activity of four medicinal plants against the blowfly Lucilia sericata (Diptera: Calliphoridae)," International Journal of Dermatology, vol. 48, no. 5, pp. 492-497, 2009.

[68] M. B. Isman, "Botanical insecticides: for richer, for poorer," Pest Management Science, vol. 64, no. 1, pp. 8-11, 2008.

[69] F. Nikkon, M. R. Habib, M. R. Karim, Z. Ferdousi, M. M. Rahman, and M. E. Haque, "Insecticidal activity of flower of Tagetes erecta L. against Tribolium castaneum (Herbst)," Research Journal of Agricultural and Biological Sciences, vol. 5, no. 5, pp. 748-753, 2009.

[70] J. Pemonge, M. J. Pascual-Villalobos, and C. RegnaultRoger, "Effects of material and extracts of Trigonella foenumgraecum L. against the stored product pests Tribolium castaneum (Herbst) (Coleoptera: Tenebrionidae) and Acanthoscelides obtectus (say) (Coleoptera: Bruchidae)," Journal of Stored Products Research, vol. 33, no. 3, pp. 209-217, 1997.

[71] Y. Lin, X. Ming, X. Jian, and L. Chang-Hoo, "Toxicity of Vitex negando extracts to several insect pests," Pesticides, pp. 2-6, 2004.

[72] B. Oliver-Bever, Medicinal Plants in Tropical West Africa, Cambridge University Press, Cambridge, UK, 1986.

[73] R. M. Baxter, P. C. Dandiya, S. I. Kandel, A. Okany, and G. C. Walker, "Separation of the hypnotic potentiating principles from the essential oil of Acorus Calamus L. of Indian origin by liquid-gas chromatography," Nature, vol. 185, no. 4711, pp. 466-467, 1960.

[74] F. A. Afifi, M. Salem, and A. M. Hekal, "Insecticidal properties of the extracts of lupin seed and caraway fruits against some stored product insects," Annals of Agricultural Science, vol. 34, no. 1, pp. 401-414, 1989.

[75] D. K. Weaver, F. V. Dunkel, L. Ntezurubanza, L. L. Jackson, and D. T. Stock, "The efficacy of linalool, a major component of freshly-milled Ocimum canum Sims (Lamiaceae), for protection against postharvest damage by certain stored product Coleopteran," Journal of Stored Products Research, vol. 27, no. 4, pp. 213-220, 1991.

[76] F. Tattersfield, R. P. Hobson, and C. T. Gimingham, "Pyrethrin I and II: their insecticidal valve and estimation in Pyrethrum (Chrysanthemum cinebariaefolium). I," Journal of Agricultural Science, vol. 19, pp. 266-296, 1929.

[77] P. R. Jefferies, R. F. Toia, B. Brannigan, I. Pessah, and J. E. Casida, "Ryania insecticide: analysis and biological activity of 10 natural ryanoids," Journal of Agricultural and Food Chemistry, vol. 40, no. 1, pp. 142-146, 1992.

[78] J. D. Hare and J. G. Morse, "Toxicity, persistence and potency of sabadilla alkaloid formulations to Citrus thrips (Thysanoptera: Thripidae)," Journal of Economic Entomology, vol. 90, no. 2, pp. 326-332, 1997.

[79] T. C. Sparks, G. D. Crouse, and G. Durst, "Natural products as insecticides: the biology, biochemistry and quantitative structure-activity relationships of spinosyns and spinosoids," Pest Management Science, vol. 57, no. 10, pp. 896-905, 2001.

[80] F. A. Khater, "Prospects of botanical biopesticides in insect pest management," Journal of Applied Pharmaceutical Science, vol. 2, no. 9, pp. 244-259, 2012.

[81] P. Golob and I. Gudrups, "The use of spices and medicinals as bioactive protectants for grains," FAO Agricultural Sciences Bulletin 137, FAO, Rome, Italy, 1999.

[82] D. Obeng-Ofori and C. Reichmuth, "Bioactivity of eugenol, a major component of essential oil of Ocimum suave (Wild.) against four species of stored-product Coleopteran," International Journal of Pest Management, vol. 43, no. 1, pp. 89-94, 1997.

[83] A. A. Abdel-Gawad and H .A. Khatab, "Soil and plant protection methods in ancient Egypt," in Proceedings of the 2nd International Conference on Soil Pollution, pp. 19-22, 1985.

[84] J. Varma and N. K. Dubey, "Prospectives of botanical and microbial products as pesticides of tomorrow," Current Science, vol. 76, no. 2, pp. 172-179, 1999.

[85] A. Hassanalli and W. Lwande, "Antipest secondary metabolites from African plants," in Insecticides of Plant Origin, J. T. Arnason, B. J. R. Philogene, and P. Morand, Eds., ACS Symposium Series, pp. 78-94, American Chemical Society, Washington, DC, USA, 1989.

[86] Y. Akhtar, Y. R. Yeoung, and M. B. Isman, "Comparative bioactivity of selected extracts from Meliaceae and some commercial botanical insecticides against two noctuid caterpillars, Trichoplusia ni and Pseudaletia unipuncta," Phytochemistry Reviews, vol. 7, no. 1, pp. 77-88, 2008.

[87] A. K. Tripathi, S. Upadhyay, M. Bhuiyan, and P. R. Bhattacharya, "A review on prospects of essential oils as biopesticides in insect-pest management," Journal of Pharmocological Phytotheraphy, vol. 1, no. 5, pp. 52-63, 2009.

[88] S. Ahmed and B. Koppel, "Plant extracts for pest control: village level processing and use by limited resource farmers," 
in Proceedings of the American Association for the Advancement of Science Annual Meeting, Los Angeles, Calif, USA, May 1985.

[89] J. L. Wolfson, R. E. Shade, P. E. Mentzer, and L. L. Murdock, "Efficacy of ash for controlling infestations of Callosobruchus maculatus (F.) (Coleoptera: Bruchidae) in stored cowpeas," Journal of Stored Products Research, vol. 27, no. 4, pp. 239243, 1991.

[90] R. G. Powel, "Higher plants as a source of new insecticidal compounds," Pesticide Science, vol. 27, pp. 228-229, 1989.

[91] E. O. Owusu, "Effect of some Ghanaian plant components on control of two stored-product insect pests of cereals," Journal of Stored Products Research, vol. 37, no. 1, pp. 85-91, 2001.

[92] R. C. Saxena, G. Jillani, and A. A. Kareem, "Effects of neem on stored grain insects," in Focus on Phytochemical Pesticides, Volume 1: The Neem Tree, M. Jacobson, Ed., pp. 97-111, CRC Press, Boca Raton, Fla, USA, 1988.

[93] A. Chatterjee, B. Das, N. Aditychaudhury, and S. Debkirtaniya, "Note on insecticidal properties of the seeds of Jatropha gossypifolia Linn," Indian Journal of Agricultural Science, vol. 50, no. 8, pp. 637-638, 1980.

[94] M. J. Sim, D. R. Choi, and Y. J. Ahn, "Vapor phase toxicity of plant essential oils to Cadra cautella (Lepidoptera: Pyralidae)," Journal of Economic Entomology, vol. 99, no. 2, pp. 593-598, 2006.

[95] G. Singh and K. Upadhyay, "Essential oils: a potent source of natural pesticides," Journal of Scientific and Industrial Research, vol. 52, pp. 676-683, 1993.

[96] M. Mariappan, S. Jayaraj, and R. C. Saxena, "Effect of nonedible seed oils on survival of Nephotettix virescens (Homoptera: Cicadellidae) and on transmission of rice tungro virus," Journal of Economic Entomology, vol. 81, no. 5, pp. 1369-1372, 1988.

[97] R. C. Saxena, O. P. Dixit, and P. Sukumaran, "Laboratory assessment of indigenous plant extracts for anti-juvenile hormone activity in Culex quinquefasciatus," Indian Journal of Medical Research A, vol. 95, pp. 204-206, 1992.

[98] K. C. Devi and S. S. Devi, "Insecticidal and oviposition deterrent properties of some spices against coleopteran beetle, Sitophilus oryzae," Journal of Food Science and Technology, pp. $1-5,2011$.

[99] M. F. Maia and S. J. Moore, "Plant-based insect repellents: a review of their efficacy, development and testing," Malaria Journal, vol. 10, no. 1, article S11, pp. 1-15, 2011.

[100] Y. S. Xie, P. G. Fields, and M. B. Isman, "Repellency and toxicity of azadirachtin and neem concentrates to three stored-product beetles," Journal of Economic Entomology, vol. 88, no. 4, pp. 1024-1031, 1995.

[101] O. Koul, S. Walia, and G. S. Dhaliwal, "Essential oils as green pesticides: potential and constraints," Biopesticide International, vol. 4, no. 1, pp. 63-88, 2008.

[102] S. J. Boeke, I. R. Baumgart, J. J. A. Van Loon, A. Van Huis, M. Dicke, and D. K. Kossou, "Toxicity and repellence of African plants traditionally used for the protection of stored cowpea against Callosobruchus maculatus," Journal of Stored Products Research, vol. 40, no. 4, pp. 423-438, 2004.

[103] A. K. Tripathi, V. Prajapati, A. Ahmad, K. K. Aggarwal, and S. P. S. Khanuja, "Piperitenone oxide as toxic, repellent, and reproduction retardant toward malarial vector Anopheles stephensi (Diptera: Anophelinae)," Journal of Medical Entomology, vol. 41, no. 4, pp. 691-698, 2004.

[104] K. Munakata, "Insect antifeedants of Spodoptera litura in plants," in Host Plant Resistance to Pests, P. A. Hedin, Ed., vol. 62 of ACS Symposium Series, pp. 185-196, American Chemical Society, Washington, DC, USA, 1997.

[105] R. C. Saxena, G. Jilani, and A. A. Kareem, "Effects of neem on stored grain insects. Focus on phytochemical pesticides," Florida Entomology, vol. 1, pp. 97-111, 1988.

[106] F. A. Talukder and P. E. Howse, "Isolation of secondary plant compounds from Aphanamixis polystachya as feeding deterrents against adult Tribolium castaneum (Coleoptera: Tenebrionidae)," Journal of Stored Products Research, vol. 107, no. 5, pp. 395-402, 2000.

[107] L. A. Hummelbrunner and M. B. Isman, "Acute, sublethal, antifeedant, and synergistic effects of monoterpenoid essential oil compounds on the tobacco cutworm, Spodoptera litura (Lep., Noctuidae)," Journal of Agricultural and Food Chemistry, vol. 49, no. 2, pp. 715-720, 2001.

[108] Z. L. Liu, Y. J. Xu, J. Wu, S. H. Goh, and S. H. Ho, "Feeding deterrents from Dictamnus dasycarpus Turcz against two stored-product insects," Journal of Agricultural and Food Chemistry, vol. 50, no. 6, pp. 1447-1450, 2002.

[109] H. C. F. Su and R. Horvat, "Isolation and characterization of four major components from insecticidally active lemon peel extract," Journal of Agricultural and Food Chemistry, vol. 35, no. 4, pp. 509-511, 1987.

[110] H. C. F. Su, "Toxicity and repellency of Chenopodium oil to four species of stored-product insects," Journal of Entomological Science, vol. 26, pp. 178-182, 1991.

[111] D. K. Weaver, F. V. Dunkel, L. Ntezurubanza, L. L. Jackson, and D. T. Stock, "The efficacy of linalool, a major component of freshly-milled Ocimum canum Sims (Lamiaceae), for protection against postharvest damage by certain stored product Coleopteran," Journal of Stored Products Research, vol. 27, no. 4, pp. 213-220, 1991.

[112] A. K. Tripathi, V. Prajapati, K. K. Aggarwal, S. P. S. Khanuja, and S. Kumar, "Repellency and toxicity of oil from Artemisia annua to certain stored-product beetles," Journal of Economic Entomology, vol. 93, no. 1, pp. 43-47, 2000.

[113] C. Channoo, S. Tantakom, S. Jiwajinda, and S. Isichaikul, "Fumigation toxicity of eucalyptus oil against three storedproduct beetles," Thailand Journal of Agricultural Science, vol. 35, no. 5, pp. 265-272, 2002.

[114] T. S. L. Ngamo, I. Ngatanko, M. B. Ngassoum, P. M. Mapongmestsem, and T. Hance, "Persistence of insecticidal activities of crude essential oils of three aromatic plants towards four major stored product insect pests," African Journal of Agricultural Research, vol. 2, pp. 173-177, 2007.

[115] M. J. Pascual-Villalobos and A. Robledo, "Screening for antiinsect activity in Mediterranean plants," Industrial Crops and Products, vol. 8, no. 3, pp. 183-194, 1998.

[116] Y. Huang, S. X. Chen, and S. H. Ho, "Bioactivities of methyl allyl disulfide and diallyl trisulfide from essential oil of garlic to two species of stored-product pests, Sitophilus zeamais (Coleoptera: Curculionidae) and Tribolium castaneum (Coleoptera: Tenebrionidae)," Journal of Economic Entomology, vol. 93, no. 2, pp. 537-543, 2000.

[117] M. D. M. Rahman, "Some promising physical, botanical and chemical methods for the protection of grain legumes against bruchids in storage under Bangladesh conditions," in Bruchids and Legumes: Economics, Ecology and Coevolution, K. Fujii, A. M. R. Gatehouse, C. D. Johnson, R. Mitchell, and T. Yoshida, Eds., pp. 63-73, Kluwer Academic Publishers, Dordrecht, The Netherlands, 1990.

[118] I. Tunç, B. M. Berger, F. Erler, and F. Dagli, "Ovicidal activity of essential oils from five plants against two stored-product 
insects," Journal of Stored Products Research, vol. 36, no. 2, pp. 161-168, 2000.

[119] S. M. Kéita, C. Vincent, J. P. Schmit, J. T. Arnason, and A. Bélanger, "Efficacy of essential oil of Ocimum basilicum L. and O. gratissimum L. applied as an insecticidal fumigant and powder to control Callosobruchus maculatus (Fab.) (Coleoptera: Bruchidae)," Journal of Stored Products Research, vol. 37, no. 4, pp. 339-349, 2001.

[120] I. Onu and M. Aliyu, "Evaluation of powdered fruits of four peppers (Capsicum spp.) for the control of Callosobruchus maculatus (F) on stored cowpea seed," International Journal of Pest Management, vol. 41, no. 3, pp. 143-145, 1995.

[121] E. Shaaya, M. Kostjukovski, J. Eilberg, and C. Sukprakarn, "Plant oils as fumigants and contact insecticides for the control of stored-product insects," Journal of Stored Products Research, vol. 33, no. 1, pp. 7-15, 1997.

[122] F. Bakkali, S. Averbeck, D. Averbeck, and M. Idaomar, "Biological effects of essential oils-a review," Food and Chemical Toxicology, vol. 46, no. 2, pp. 446-475, 2008.

[123] M. Jacobson, "Botanical pesticides: past, present and future," in Insecticides of Plant Origin, J. J. Arnason, B. R. Philogen, and P. Morand, Eds., vol. 387 of ACS Symposium Series, pp. 1-10, Washington, DC, USA, 1989.

[124] M. G. Jotwani P. Sircar, "Neem seed as protectant against stored grain pests infesting wheat seed," Indian Journal of Entomology, vol. 27, pp. 160-164, 1965.

[125] D. A. Devi and N. Mohandas, "Relative efficacy of some antifeedants and deterrents against insect pests of stored paddy," Entomon, vol. 7, no. 3, pp. 261-264, 1982.

[126] J. Pereira and R. Wohlgemuth, "Neem (Azadirachta indica A. Juss) of West African origin as a protectant of stored maize," Journal of Applied Entomology, vol. 94, pp. 208-214, 1982.

[127] S. M. Ahmed, "Neem (Azadirachta Indica A. Juss) a safer insecticide potentials and prospects," Pest Management, pp. $1-3,1994$.

[128] S. R. S. Yadava and K. N. Bhatnagar, "A preliminary study on the protection of stored cowpea grains against pulse beetle, by indigenous plant products," Pesticides, vol. 21, no. 8, pp. 25-29, 1987.

[129] H. Schmutterer, "Properties and potential of natural pesticides from the neem tree, Azadirachta indica," Annual Review of Entomology, vol. 35, pp. 271-297, 1990.

[130] A. Hassanali, W. Lwande, N. Ole-Silayo, L. Moreka, S. Nokoe, and A. Chapya, "Weevil repellent constituents of Ocimum suave leaves and Eugenia caryophyllata cloves used as grain protectants in parts of Eastern Africa," Discovery and Innovation, vol. 2, no. 2, pp. 91-95, 1990.

[131] S. N. Tiwari, "Efficacy of some plant products as grain protectants against Rhizopertha dominica (F.) (Coleoptera; Bostrichidae)," International Journal of Pest Management, vol. 40, no. 1, pp. 94-97, 1994.

[132] J. Brice, C. Moss, N. Marsland et al., "Post-harvest constraints and opportunities in cereal and legume production production system in northern Ghana," NRI Research Report 85, 1996.

[133] K. N. Don-Pedro, "Toxicity of some citrus peels to Dermestes maculatus Deg. and Callosobruchus maculatus (F)," Journal of Stored Products Research, vol. 21, no. 1, pp. 31-34, 1985.

[134] R. B. Doharey, R. N. Katiyar, and K. M. Singh, "Ecotoxicological studies on pulse beetles infesting green gram," Bulletin of Grain Technology, vol. 28, no. 2, pp. 116-119, 1990.

[135] D. Singh and S. S. Mehta, "Menthol containing formulation inhibits adzuki bean beetle, Callosobruchus chinensis 1 .
(Coleoptera; Bruchidae) population in pulse grain storage," Journal of Biopesticides, vol. 3, no. 3, pp. 596-603, 2010.

[136] M. B. Hertlein, G. D. Thompson, B. Subramanyam, and C. G. Athanassiou, "Spinosad: a new natural product for stored grain protection," Journal of Stored Products Research, vol. 47, no. 3, pp. 131-146, 2011.

[137] B. P. Saxena, K. Tikku, C. K. Atal, and O. Koul, "Insect antifertility and antifeedant allelochemics in Adhatoda vasica," Insect Science and its Application, vol. 7, no. 4, pp. 489-493, 1986.

[138] E. F. Asawalam and S. O. Adesiyan, "Potentials of Ocimum basilicum (Linn.) for the control of Sitophilus zeamais (Motsch)," The Nigerian Agricultural Journal, vol. 32, pp. 195-201, 2001.

[139] G. H. Schmidt, N. M. M. Ibrahim, and M. D. Abdallah, "Toxicological studies on the long-term effects of heavy metals $(\mathrm{Hg}, \mathrm{Cd}, \mathrm{Pb})$ in soil on the development of Aiolopus thalassinus (Fabr.) (Saltatoria: Acrididae)," Science of the Total Environment, vol. 107, pp. 109-133, 1991.

[140] L. A. M. Khanam, D. Talukder, A. R. Khan, and S. M. Rahman, "Insectidical properties of Royna, Aphanamixis polystachya Wall. (Parker) (Meliaceae) against Tribolium confusum Duval," Journal of Asiatic Society of Bangladesh Science, vol. 16, pp. 71-74, 1990.

[141] B. Rajasekaran and T. Kumaraswami, "Studies on increasing the efficacy on neem seed kernel extract," in Behavioural and Physiological Approaches in Pest Management, A. Regupathy and S. Jayaraj, Eds., pp. 29-30, Khadi and Village Industries Commission, Pune, India, 1985.

[142] K. Jamil, U. Rani, and G. Thyagarajan, "Water hyacinth-a potential new juvenile hormone mimic," International Pest Control, vol. 26, no. 4, pp. 106-108, 1984.

[143] B. P. Pepper and L. A. Carruth, "A new plant insecticide for control of the European corn borer," Journal of Economic Entomology, vol. 38, pp. 59-66, 1945.

[144] N. Z. Dimetry, "Prospects of botanical pesticides for the future in integrated pest management programme (IPM) with special reference to neem uses in Egypt," Archives of Phytopathology and Plant Protection, vol. 45, no. 10, pp. 1138$1161,2012$.

[145] W. M. Davidson, "Rotenone as a contact insecticide," Journal of Economic Entomology, vol. 23, no. 5, pp. 868-874, 1930.

[146] L. G. Copping and S. O. Duke, "Natural products that have been used commercially as crop protection agents," Pest Management Science, vol. 63, no. 6, pp. 524-554, 2007.

[147] J. Miyamoto, "Degradation, metabolism and toxicity of synthetic pyrethroids," Environmental Health Perspectives, vol. 14, pp. 15-28, 1976.

[148] J. E. Brooks, P. J. Savarie, and J. J. Johnston, "The oral and dermal toxicity of selected chemicals to brown tree snakes (Boiga irregularis)," Wildlife Research, vol. 25, no. 4, pp. 427435, 1998.

[149] J. E. Casida and G. B Quistad, Pyrethrum Flowers: Production, Chemistry, Toxicology and Uses, Oxford University Press, Oxford, UK, 1995.

[150] J. E. Casida, "Pyrethrum flowers and pyrethroid insecticides," Environmental Health Perspectives, vol. 34, pp. 189-202, 1980.

[151] I. Yamomoto, "Nicotine to nicotinoids," in Nicotinoid Insecticides and the Nicotinic Acetylcholine Receptor, I. Yamomoto and J. E Casida, Eds., Springer, Tokoyo, Japan, 1999.

[152] I. Ujvary, "Nicotine and other alkaloids," in Nicotinoid Insecticides and the Nicotinic Acetylcholine Receptor, I. Yamomoto 
and J. E Casida, Eds., pp. 29-70, Springer, Tokoyo, Japan, 1999.

[153] N. Zong and C. Wang, "Induction of nicotine in tobacco by herbivory and its relation to glucose oxidase activity in the labial gland of three noctuid caterpillars," Chinese Science Bulletin, vol. 49, no. 15, pp. 1596-1601, 2004.

[154] H. Rembold, "Azadirachtins: their structure and mode of action," in Insecticides of Plant Origin, J. T. Arnason, B. J. R. Philogene, and P. Morand, Eds., ACS Symposium series, pp. 150-163, American Chemical Society, Washington DC, USA, 1989.

[155] I. Putter, J. G. Mac Connell, and F. A. Preiser, "Avermectins: novel insecticides, acaricides and nematicides from a soil microorganism," Cellular and Molecular Life Sciences, vol. 37, no. 9, pp. 963-964, 1981.

[156] H. Mrozik, P. Eskola, B. O. Linn et al., "Discovery of novel avermectins with unprecedented insecticidal activity," Cellular and Molecular Life Sciences, vol. 45, no. 3, pp. 315316, 1989.

[157] Y. Deng, "House fly brain $\gamma$-aminobutyric acid-gated chloride channel: target for multiple classes of insecticides," Pesticide Biochemistry and Physiology, vol. 41, no. 1, pp. 6065, 1991.

[158] L. G. Copping and J. J. Menn, "Biopesticides: a review of their action, applications and efficacy," Pest Management Science, vol. 56, pp. 651-676, 2000.

[159] D. E. Snyder, J. Meyer, A. G. Zimmermann et al., "Preliminary studies on the effectiveness of the novel pulicide, spinosad, for the treatment and control of fleas on dogs," Veterinary Parasitology, vol. 150, no. 4, pp. 345-351, 2007.

[160] R. W. Wiseman, E. C. Miller, J. A. Miller, and A. Liem, "Structure-activity studies of the hepatocarcinogenicities of alkenylbenzene derivatives related to estragole and safrole on administration to preweanling male C57BL/6 J x C3H/HeJ F1 mice," Cancer Research, vol. 47, no. 9, pp. 2275-2283, 1987.

[161] W. Goggelmann and O. Schimmer, "Mutagenicity testing of $\beta$-asarone and commercial calamus drugs with Salmonella typhimurium," Mutation Research, vol. 121, no. 3-4, pp. 191194, 1983.

[162] G. Abel, "Chromosomenschadigende Wiruking von $\beta$ asarone in menschlichen Lymphocyten," Planta Medica, vol. 53, no. 3, pp. 251-253, 1987.

[163] J. Lu and Y. Shi, "The bioactivity of essential oil from Ailanthus altissima Swingle (Sapindales: Simasoubaceae) bark on Lasioderma serricorne (Fabricus) (Coleoptera: Anobiidae)," Advanced Material Research, vol. 365, pp. 428-432, 2012.

[164] D. Obeng-Ofori, “The use of botanicals by resource poor farmers in Africa and Asia for the protection of stored agricultural products," Stewart Postharvest Review, vol. 3, no. 6, article 10, 2007.

[165] D. Obeng-Ofori, "Residual insecticides, inert dusts and botanicals for the protection of durable stored products against pest infestation in developing countries," in Stored Products Protection, M. O. Carvalho, P. G. Fields, C. S. Adler et al., Eds., Proceedings of the 10th International Working Conference on Stored Product Protection, pp. 774-788, Julius-KühnArchiv 425, 2010. 

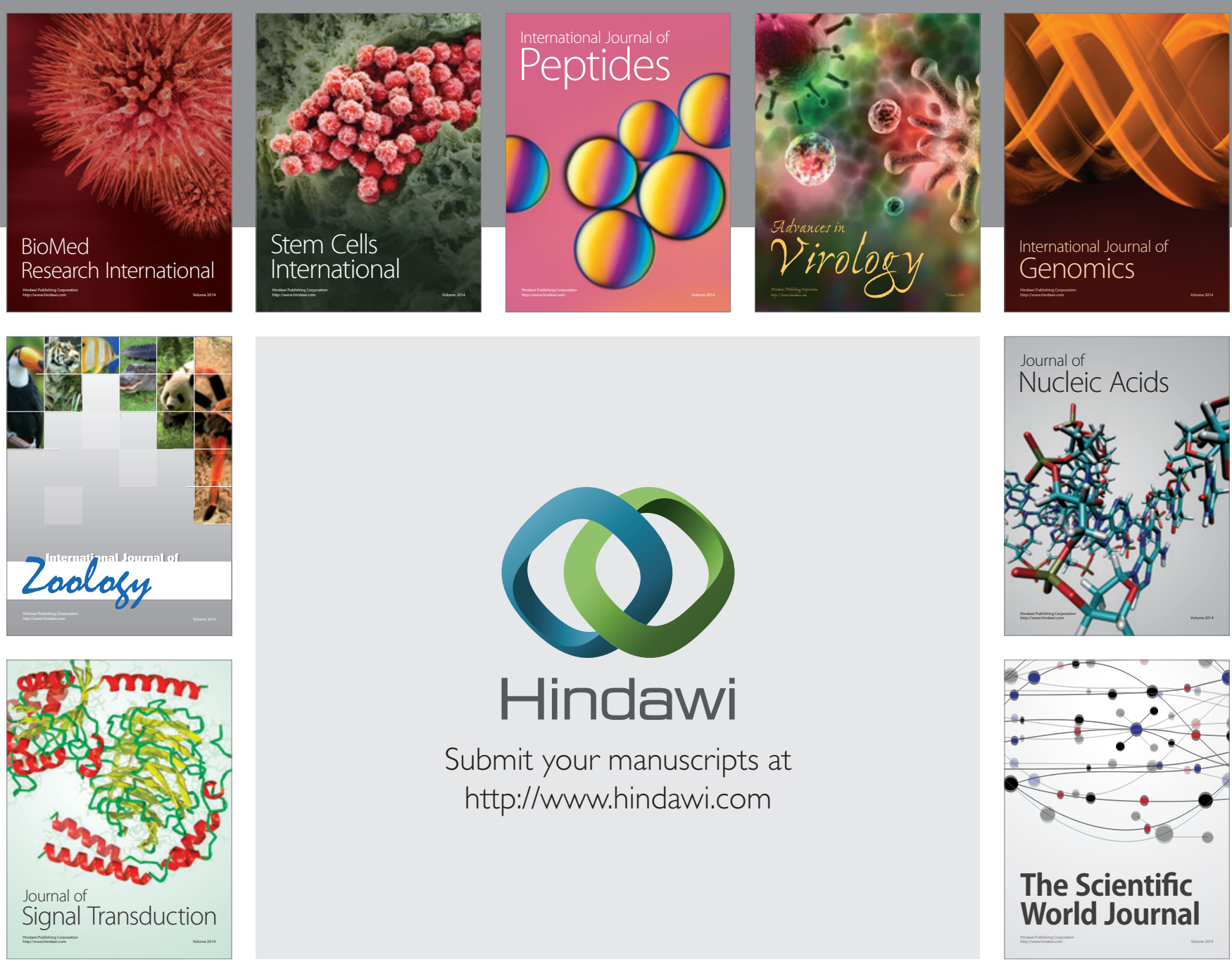

Submit your manuscripts at

http://www.hindawi.com
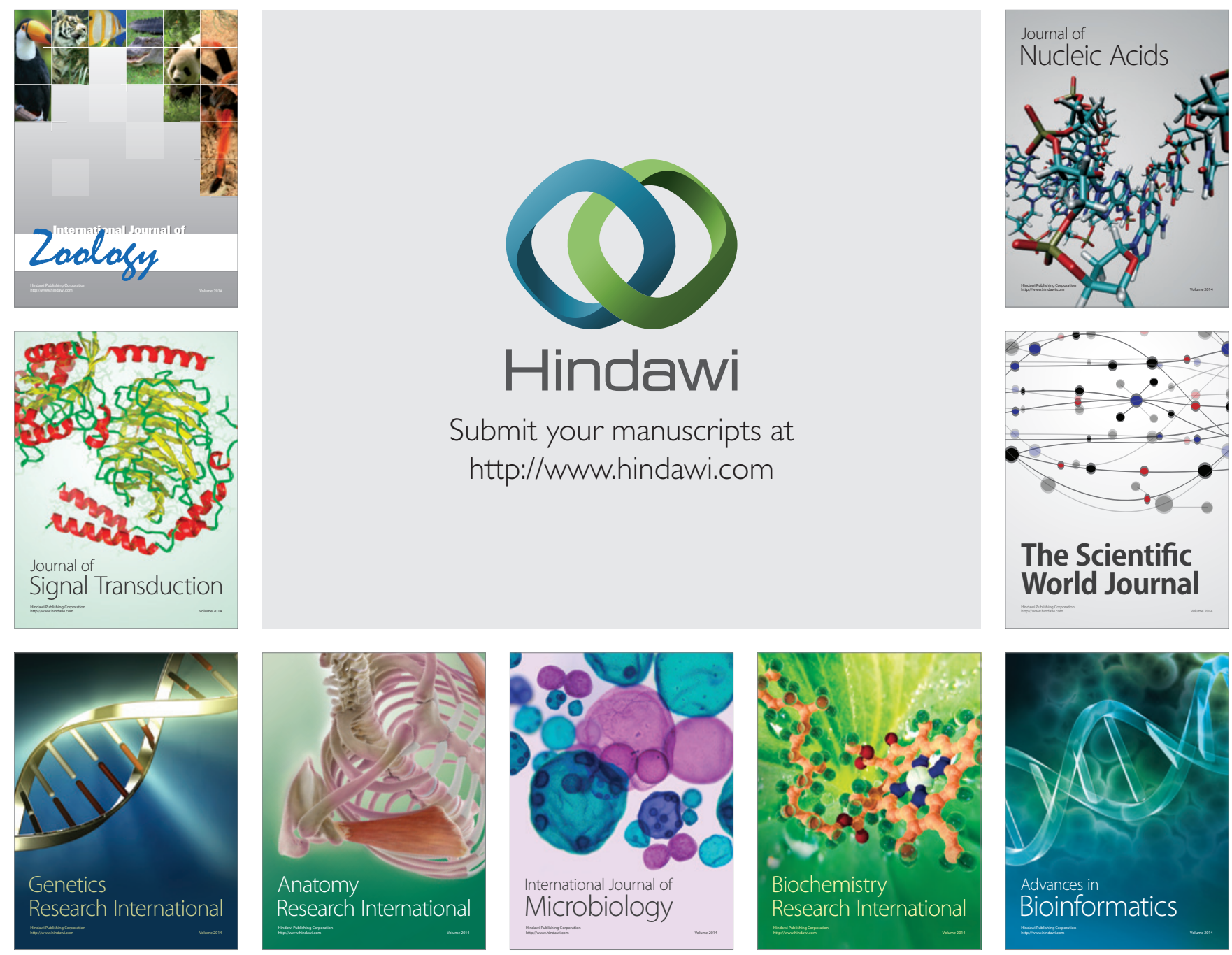

The Scientific World Journal
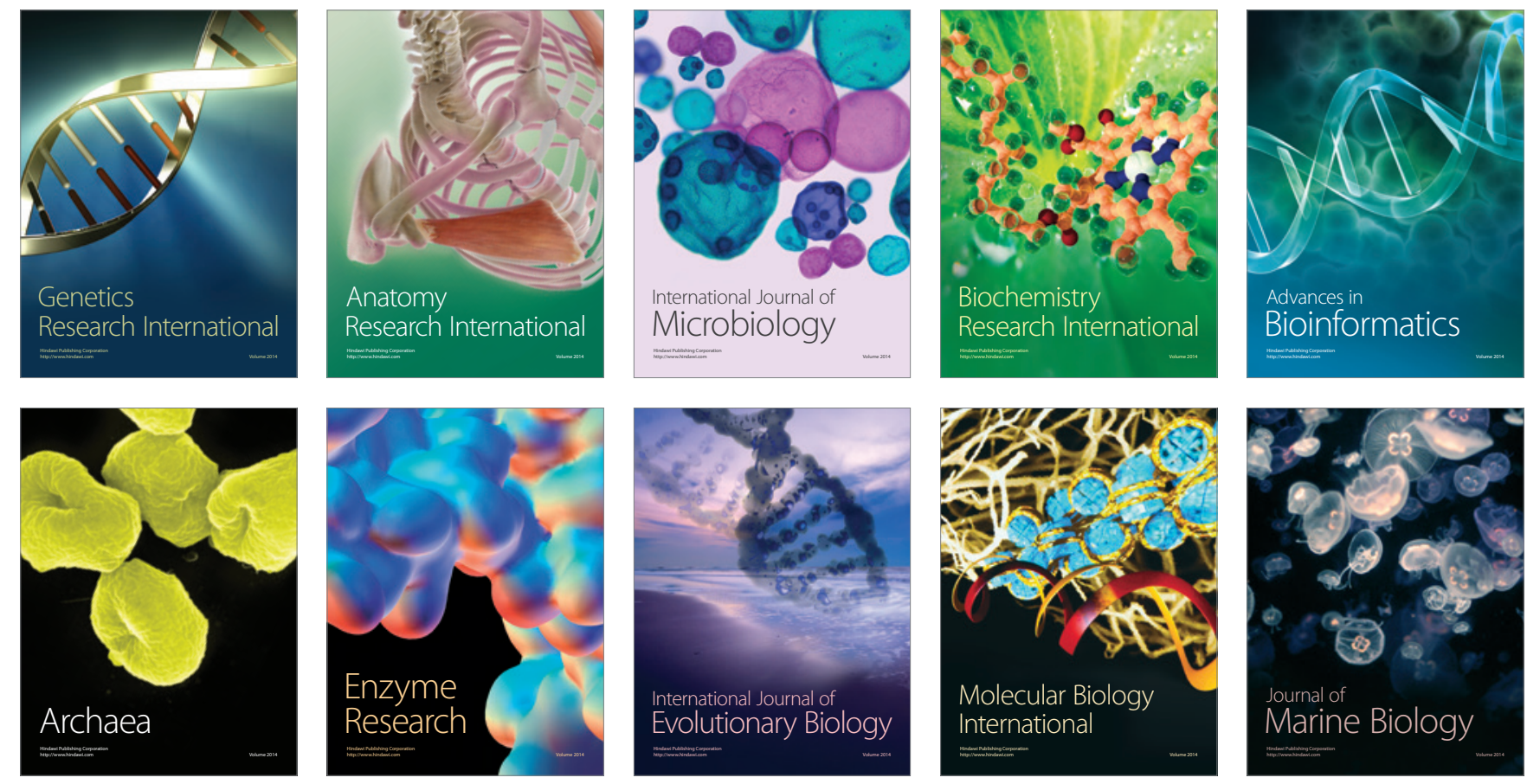